\title{
Consciousness and Smoke of Clouding Waves of
}

\section{Desires}

\author{
Kanta Arora \\ Sanskrit Department, Dayalbagh Educational Institute (Deemed University), Dayalbagh, Agra, India
}

\begin{abstract}
There are, vide spread, religious beliefs that creation is the result of desire of the Ultimate Reality or the Divine Force for its expansion. In this paper I endeavour to explain that human form is disintegrated part of that divine desire. The tendency or desire to grow and expand in the individuals is the force behind every activity of the world. Consciousness packed in the city of human body is a pack of desires. The clouds of strong desires well up from within and surround individuals to push them forward to action, will and determination. One has to distinguish between the crazy desires of mind for temporary pleasures and desires for permanent bliss.
\end{abstract}

Key words: Rig Veda, Nasadiya Sukta, Bible, Qur’an.

\section{Introduction}

Indian scriptures of religious philosophy declare that desire was the earliest seed and thought was the product. The sages who searched in their hearts with wisdom, found the bond of being in the non being. Nasadiya Sukta of Rig Veda starts with a note that in the beginning nothing existed neither being nor non being. There was complete darkness hidden by darkness. First desire sprouted forth earliest which produced thought.

Bible's book of Genesis describes the first divine command as 'Let there be light' and there was light. Many verses of Qur'an also describe that the Creator of heavens and the earth from nothingness, He has only to say when He wills a thing: "Be" and it is that is how God creates what He wills.

All above findings point towards a common religious faith that the divine will to grow or expand is the force behind all creation. It was the first desire of the consciousness to create a playmate or to be many which lead to its transformation into all creation like extended waves of the sea.

Corresponding author: Kanta Arora, Dr., M.A., Ph.D., research field: philosophy of life in the light of enlightened experiential and physical realities of life.

\section{Materials}

Ignorant of any above quoted scriptures, I in my earlier age once wrote:

"Ae khuda de muze ik aisee zindgi, Har sham ik tammana- hr subhah ik umeed"

O God, give me a life wherein every evening I have a desire and every morning a hope. I wondered as to how an individual can be considered alive without any desire and hope.

Today I consider human form to be a disintegrated spark of that Divine desire which promotes universal expansion, maintenance and dissolution activity. I find reasons to believe that to be conscious is to be desirous, Self-Consciousness (I-ness) is desire itself. The tendency (desire) to grow and expand is the force behind every activity of the world. Consciousness confined in the city of human body is a pack of desires. The desire transforms itself to self awareness, awareness moves one to action. Action provides satisfaction to some extent. Dissatisfactions again push for more desires and action.

The clouding waves of desires well up from within and surround living beings always. One feels burnt with desires and gasps for breath like a drowning person in the ocean of thoughts for their fulfilment. 
One is pushed up to will and determination. For when a desire arises, man wills, then he thinks in mind, utters speech and acts and reaches as for as his will goes. Will is greater than mind. Mind is the seat for thought and feeling which promotes will. When one goes in determination to struggle to fulfil his desires, he experiences wonderful moments of beauty, love and bliss amongst all the bright and beautiful things of this word all around him. One is fascinated and entrapped in their enjoyment and seeks rest with them. Seed of desire sprouts forth, expands to live its life and reverts back to the source.

Smoke of burning desires creates attachments with the transitory world and blind individual vision. One cannot distinguish between as to what is good and what is pleasant or what is permanent and temporary for him. He becomes crazy in the whirlpool of temporary pleasures of life. These desires become the root cause of al pain and sufferings in life and a trap falling into pangs of birth and death again and again. Eastern traditions clearly distinguish between the crazy desires of mind leading one to stray for pleasant things which are transitory nature and advice to distinguish between the good and pleasant with an aim to seek permanent bliss by going deep within for the knowledge of divinity of the human Self. 'Man Know Thy Self' (Refer to my poster presentation in TSC-2013).

But the extended waves of desire have a strong tendency to calm down and revert back to its original position when one realises that his stay in this world is very short. He has to leave this world one day, leaving behind all his relations and accumulations and cannot carry anything with him beyond this life. One starts to find the meaning and purpose of life and gropes in wilderness to find his real love and benefactor. In spite of all comforts of the world and fulfilments sometimes one weeps and cries to know who he is? Where from has he come? How can he experience permanent peace in life and free himself from the ordeals of life and death.

Again a burning desire pulls from within the Self itself to revert back for the experience of union with the ultimate reality. One falls flat on the ground or raises his hands towards the sky to pray with a desire to understand the mystery of life.

\section{Conclusions}

Consciousness is a stream of desires extending its current outward to enjoy temporal worldly pleasures, with a tendency to revert inwards for eternal bliss. 